\title{
Potentiality for the Application of Value Engineering in the Construction Industry at the Design Stage
}

\author{
Dr.Abdallah M.Awadalla ${ }^{1}$
}

\begin{abstract}
Value Engineering (VE) is defined as a systematic application of a recognized approach by a multidisciplined team to identify the functions of a product or a system and to establish a worth for that function. Alternatives are generated through the creative thinking. The needed functions are provided to accomplish purpose of the project, reliability and at the lowest life cycle cost without sacrificing safety, necessary quality and environmental attributes. This paper aims at investigating the effectiveness of $V E$ as an approach that could improve the design process which is considered as an important stage in the project life cycle. Current research has shown that the impact of design on the total cost of the project is estimated as 50\%. Hence, this study is concentrated at the design stage.

To assess the actual practice during the design process, a questionnaire was designed and sent to 15 respondents. This comprised design firms, engineers as well as clients. The questionnaire main objective was to find out how VE studies are conducted and to gauge the impact on the design of the studied projects. The questions were set to investigate to what extent VE components (function, quality and cost) were applied on those projects under study and their impact on design. The Statistical analysis was conduced using SPSS 10. Descriptive statistics methods were used for organizing and analyzing data. Chi-square tests were used to test the research hypotheses and to make comparisons between observed and expected frequencies. The results obtained from the analysis of the collected data showed that the poor performance in the design process which leads to cost and time overrun and low quality is due to the inefficient methods of conducting the brief with the clients. The tendency of designers to produce expensive designs to show their capabilities without achieving the required functions of the project is also found to be one of the defects in the design process.

The Sudanese government and the private sector are recommended to adopt VE. Architects, engineers, and other professionals are recommended to play part in the spread of this technique among their firms. The research recommended further studies to develop and improve VE techniques and tools.
\end{abstract}
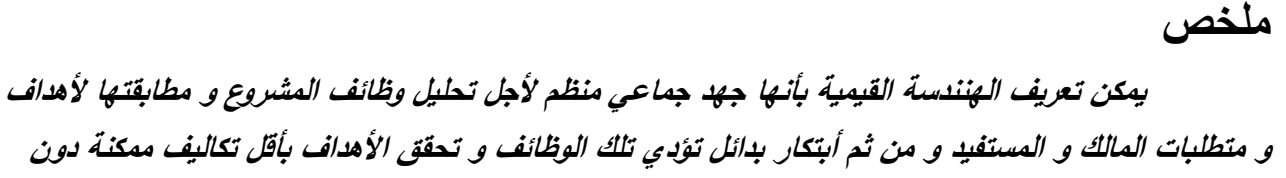

${ }^{1}$ Faculty of Engineering Sciences-Omdurman Islamic University- Fellow (SES) 


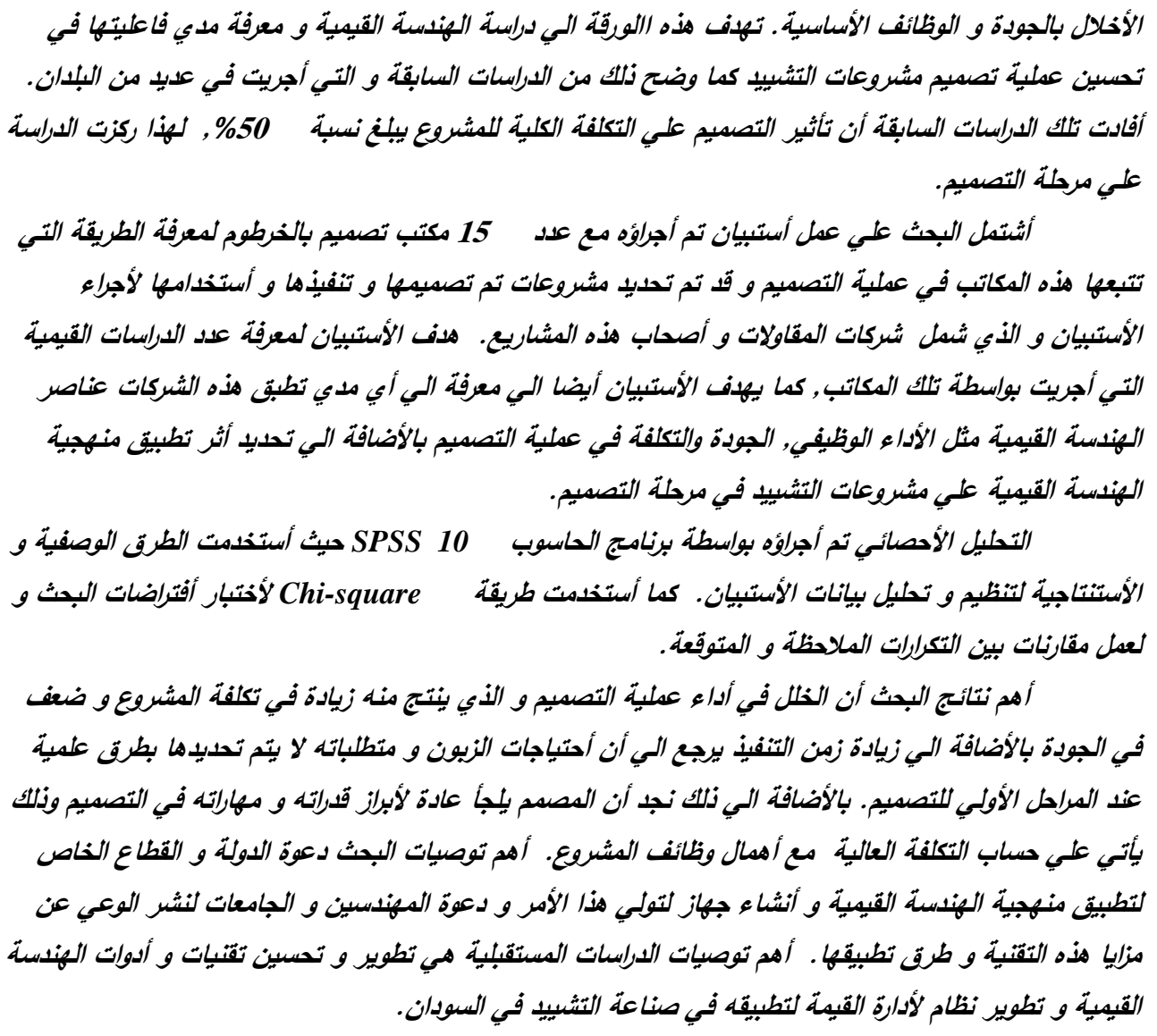

\section{Introduction}

The amount of work undertaken by construction firms in the public and private sectors depends on the available volume of financial resources. However, finance extremely depends on how well the country as a whole is doing regarding its balance of payments. It is really safe to consider that the construction industry is the barometer of the countrys progress (Foster 1986).

The construction process composes of three stages: conception, design, and construction. Project conception is the recognition of the client's needs that can be satisfied by a physical structure. The project design phase translates the primary concept into an expression of a spatial 
form that will satisfy the client's requirements in an optimum economic manner. Construction operations constitute the final phase of the process as they create the physical form that satisfies the conception and permits the realization of the design.

Common problems affecting construction industry in developing countries include lack of management skills, shortage of skilled labor, low productivity, shortage of supplies, bad quality of supplies and lack of equipments. Shortage of materials, financing and payments for completed works, and poor contract management are the three major causes of delay and cost overruns. Price fluctuations, delay, and fraudulent practices were identified as the most important factors that could cause overruns. Delay and cost overruns due to human inefficiency can be minimized through good management strategies.

\section{Problem Statement}

Design is the most important stage that affects quality, cost and the overall performance of the project. Architectural and structural errors, which may occur during the design process, can lead to unnecessary costs, poor quality and low productivity. Owners and users who do not explicitly explain their basic needs at the early stages of design will be astonished to discover late that the cost is very high while their requirements are not fulfilled. Usually the functions of the different components and elements of the project and even the relationship between design, quality and cost are not clear for designers, constructors and owners.

\section{Aims and Objectives of the Study}

The study aims at investigating the effect of conducting VE studies at the design stage. Thus the objectives of the study cover the following:

1. To recognize the relationship between the client's requirements and the parameters of the design process.

2. To examine the relationship between VE techniques and the design process in the Sudanese design firms. 


\section{The Hypotheses}

Four hypotheses were developed to test the stated objectives as follows:

1. There is no relationship between the client's requirements and the client's brief conducted by the designer.

2. There is no relationship between the client's requirements and the criteria used in selection of materials and components to be incorporated in project.

3. There is no relationship between functional analysis and the criteria used in selection of materials and components to be incorporated in project.

4. There is no relationship between the methods of evaluation of alternatives and the criteria used in selection of materials and components to be incorporated in project.

The ability to influence the course of a design is much greater at the beginning of a project, when the amount of money being spent is low. As the design becomes more detailed, however, the amount of money already invested increases; and any change has the potential to be costly. Once the project is in construction, any changes can be extremely costly both in time and in actual costs. Gernerd (1993) stated that VE analysis at the conceptual design stage is conducted when the preferred alternative has been selected. Project functions such, interrelationship of project elements, optimum location and magnitude of project elements, treatment processes, supplyalternatives, system and subsystem selection, mitigation measures, resource impacts and other major project decisions have been conceptually designed through the project planning process.

Before formal project design, these project elements can be systematically evaluated at conceptual stage of design using VE technique.

\section{Literature Review}

Lawrence Miles, an engineer at the General Electric Company in U.S.A., was assigned to design parts from the available raw materials due to the shortage which happened as a consequence of the Second World War. Instead of focusing on the design of the parts he was responsible for, he focused on the function that these parts had to perform. He found that the result was invariably simpler, economical and performed better. The 
emphasis on function remains the driving force in VE today (George and Palmer 1995). Since then more organizations started to adopt the VE techniques. In 1954, this technique was adopted by the American Navy where it was called VE in order to reflect the nature of their engineering work in the application of the technique at the stage of design prior to the commencement of production. In 1956, the Army Ordnance Corps established a VE programme and the Air Force became interested to apply this new methodology in 1961.

Before 1972, the interest of the construction industry in this technique was very limited. In 1972, the 12th Annual Conference of the Society of American Value Engineers (SAVE) encouraged the application of VE in the construction industry (O'Brien, 1976). The use of VE techniques had spread gradually through North America and by the early 1970s; it had been introduced in Japan, Europe and Australia. Today, Japan followed by Germany and the U.S.A. are the biggest users of the VE system (Grosvenor, 1997). Other countries that are using this technique formally include Canada, France, China, Hong Kong, Hungary, India, Korea, New Zealand, Saudi Arabia, Taiwan, the United Kingdom and the United Arab Emirates. Because of the successful applications of VE in Saudi Arabia, it was spread to Egypt, Lebanon and Arabian Gulf countries (SAVE International 2000).

Al-Yousefi (2005) reported that there are about 1900 specialists in VE all over the world, $10 \%$ of them are in the Arabian Gulf area conducting 80 to 100 VE studies yearly. The monetary saving of these studies is about five billion Saudi Ryials. Also, VE methodology is taught as a scientific subject in five universities and institutes. Therefore, the Gulf countries come thirdly in the world after U.S.A. and Japan in practicing VE.

Al-Yousifi (2000) reported that according to a statistical survey carried out in U.S.A. and K.S.A., the effect of design on the total cost of the project was found to be $49 \%$. This has been confirmed by Al-Khoitter (2000). Wuebbenhorst (1984) stated that about $75 \%$ of the expected life cycle cost of a project depends on the decisions taken during the early stages of design. Consequently, the ability to influence the design course is much greater at the beginning of a project when the amount of money being spent is low. 
Value engineering may not be well known among engineers working in the construction industry in Sudan. Fortunately, a considerable number of theses have been conducted in this subject as partial fulfillment for obtaining B.Sc. degree at the Faculty of Engineering in Sudan University of Science and Technology and Omdurman Islamic University during the last years. In addition, M.Sc. and Ph.D. theses on VE have been carried out at Sudan University of Science and Technology. Two seminars on VE were made in Khartoum by Abdel-Aziz Suliman Al-Yousifi, a Certified Value Specialist from Saudi Arabia on 2002 and 2005.

\section{The Research Methodology}

The review of the literature provided the historical perspective and in-depth knowledge of the subject and enriched the content of the study. It has also highlighted the significant impact of design on construction process and it provided a considerable amount of findings which led to the development of the hypotheses. A questionnaire was designed to collect the required data to test the hypotheses and as well the sample.

\section{Defining the Questions Areas}

Before designing the questionnaire questions, two visits were paid to large design firms to map the design process how is going. The aim of these visits was to build a concrete base of knowledge to help structuring the questionnaire questions. It was found that the design process in these firms is traditional: the design staff consists of architects, who are the majority, and civil engineers while mechanical and electrical engineers are parttimers. The design process usually starts from the manager who assigns one or two architects to carry out the preliminary design. The client's brief is not fully detailed but just represents the general outlines of the project. The architects discuss the preliminary design with the client after it is completed. In most of the cases, the client is unable to understand the drawings or he is in a hurry to get the approval of the design of his project.

Indeed, this usually results in a design not agreed upon with the client who will make many changes during construction when he realizes the components of the project. It seems that the required management systems (software such as Client-pro, Auto-brief, Brief-maker and design quality indicator) are not available in the Sudanese design firms. It has also been observed that there is no organized or scientific system for the 
selection of materials and components to be incorporated in projects. Although architects are aware of some economic measures, they compete to produce an outstanding and sophisticated design to show their capabilities. In addition, insufficient details characterize most of the Sudanese design documents.

\section{The Structure of the Questionnaire}

The interview questionnaire consisted of three sets of questions. The first set was meant to be answered by designers, the second was meant to be answered by the construction engineers and the third was meant to be answered by clients. The questions were directed for a single project that was successfully designed and constructed during the last years. In this way, the respondents (designers, construction engineers and clients) could provide data representing their different points of views about a single project. The first section of the questionnaire was meant to provide general information about the respondents and the selected projects.

The second section was different for the designer, construction engineer and the client. The designer part included questions about the client's brief, factors affecting design, criteria used for the selection of materials and components and methods of checking designs. The construction engineer part included questions about the reasons of increased costs and deficiencies in the project. The client part included questions about consultation, changes requirements, client satisfaction and deficiencies in design.

\section{Statistical Methods and Procedures}

Descriptive statistics methods are used in this research to present the data in standard tables and graphs so that it can be understood easily. The variables used in the analysis will be described in terms of frequency and percentage. Inferential statistics techniques are also used to make decisions about the surveyed sample. The statistical analysis will measure and test the relationship between different variables, namely: the client's requirements, client's brief, methods of selection of materials and components, methods of evaluation of alternatives and function analysis. Each two variables will be associated together to determine the significant 
association at 0.05 level of significance. The results are shown in Tables (17).

The statistical analysis of the data was determined using SPSS10.0 package. Chi-square was the statistical method used to test the hypotheses in this research.

\section{ANALYSIS \& DISCUSSION OF THE RESULTS}

1. Hypothesis One: There is no relationship between the client's requirements and the client's brief conducted by the designer.

Table (1): Association between "the client's requirements " \& "client's brief problems"

\begin{tabular}{|c|c|c|c|c|c|c|}
\hline & & & \multicolumn{3}{|c|}{$\begin{array}{l}\text { Problems Generally Encountered When } \\
\text { Agreeing the Design Brief with the Client }\end{array}$} & \multirow[t]{2}{*}{ Total } \\
\hline & & & $\begin{array}{l}\text { The client is } \\
\text { unable to set his } \\
\text { requirements } \\
\text { effectively }\end{array}$ & $\begin{array}{l}\text { The client is } \\
\text { setting unrealistic } \\
\text { requirements in } \\
\text { cost }\end{array}$ & $\begin{array}{l}\text { The } \\
\text { client is } \\
\text { always } \\
\text { changing } \\
\text { his mind }\end{array}$ & \\
\hline \multirow{6}{*}{$\begin{array}{c}\text { Client's } \\
\text { Require } \\
\text { ments }\end{array}$} & \multirow[t]{2}{*}{ Yes } & count & 1 & 1 & 7 & 9 \\
\hline & & $\%$ of total & $7.1 \%$ & $7.1 \%$ & $50 \%$ & $64.3 \%$ \\
\hline & \multirow[t]{2}{*}{ No } & count & 3 & 0 & $1 \%$ & $4 \%$ \\
\hline & & $\%$ of total & $21.4 \%$ & 0 & $7.1 \%$ & $28.6 \%$ \\
\hline & \multirow{2}{*}{$\begin{array}{l}\text { Not } \\
\text { sure }\end{array}$} & count & 0 & 1 & 0 & $1 \%$ \\
\hline & & $\%$ of total & 0 & $7.1 \%$ & 0 & $7.1 \%$ \\
\hline \multirow{2}{*}{\multicolumn{2}{|c|}{ Total }} & count & $4 \%$ & 2 & $8 \%$ & $14 \%$ \\
\hline & & $\%$ of total & $28.6 \%$ & $14.3 \%$ & $57.1 \%$ & $100 \%$ \\
\hline
\end{tabular}


Table (2):Chi-square test for the client's requirements \& client's brief problems

\begin{tabular}{|l|c|c|c|}
\hline & Value & df & $\begin{array}{c}\text { Asymp. Sig. } \\
\text { (2-sided) }\end{array}$ \\
\hline Pearson chi-square & $12.007^{\text {a }}$ & 4 & .017 \\
\hline
\end{tabular}

a. Result : There was a significant association at 0.05 level of significance.

2. Hypothesis Two: There is no relationship between the client's requirements and the criteria used for selection of materials and components to be incorporated in the project.

Table (3): Association between "the client's requirements \& "criteria of selection of materials"

\begin{tabular}{|c|c|c|c|c|c|c|}
\hline \multicolumn{7}{|c|}{$\mathrm{C}=\mathrm{t}=\mathrm{s}$} \\
\hline & & & & & $\begin{array}{c}\text { Customer } \\
\text { convenience }\end{array}$ & Total \\
\hline & & & $\begin{array}{c}\text { Very } \\
\text { important }\end{array}$ & Important & $\begin{array}{c}\text { Not important } \\
\text { at all }\end{array}$ & \\
\hline \multirow{6}{*}{$\begin{array}{l}\text { Client' } \\
\text { s } \\
\text { Requir } \\
\text { ements }\end{array}$} & \multirow[t]{2}{*}{ Yes } & count & 5 & 4 & 0 & 9 \\
\hline & & $\%$ of total & $35.7 \%$ & $28.6 \%$ & 0 & $64.3 \%$ \\
\hline & \multirow[t]{2}{*}{ No } & count & 0 & 3 & 1 & $4 \%$ \\
\hline & & \%of total & 0 & $21.4 \%$ & $7.1 \%$ & $28.6 \%$ \\
\hline & \multirow{2}{*}{$\begin{array}{l}\text { Not } \\
\text { sure }\end{array}$} & count & 1 & 0 & 0 & $1 \%$ \\
\hline & & $\%$ of total & $7.1 \%$ & 0 & 0 & $7.1 \%$ \\
\hline & \multirow{2}{*}{ total } & count & $6 \%$ & 7 & 1 & $14 \%$ \\
\hline & & \%of total & $42.9 \%$ & $50 \%$ & $7.1 \%$ & $100 \%$ \\
\hline
\end{tabular}

Table (4):Chi-square test for the client's requirements \& criteria of selection of materials

\begin{tabular}{|c|c|c|c|}
\hline & Value & df & \multicolumn{1}{c|}{$\begin{array}{c}\text { Asymp. Sig. } \\
\text { (2-sided) }\end{array}$} \\
\hline $\begin{array}{c}\text { Pearson chi- } \\
\text { square }\end{array}$ & $6.370^{\mathrm{a}}$ & & 4 \\
\hline
\end{tabular}

a. Result : There was a significant association at 0.05 level of significance 
3. Hypothesis three: There is no relation between functional analysis and the criteria used for selection of materials and components to be incorporated in the project.

Table (5): Association between "functional analysis" \& "criteria of selection of materials"

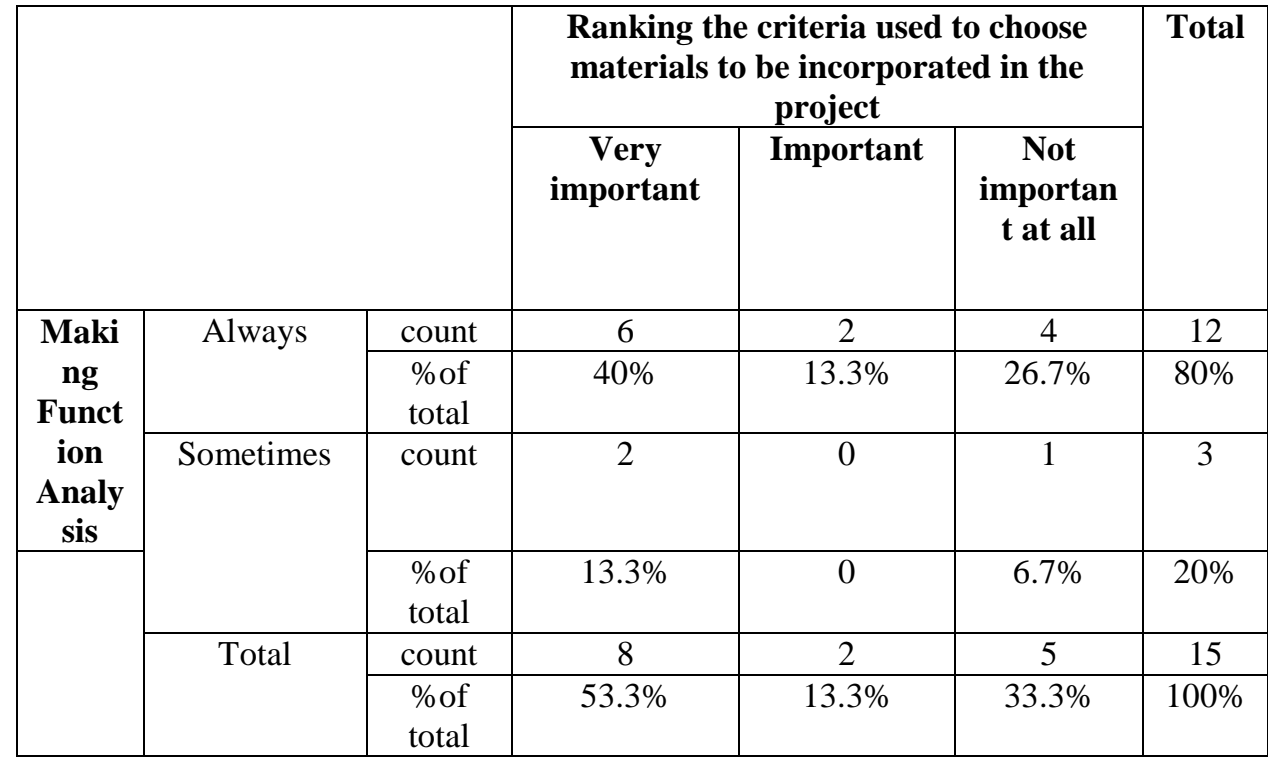

Table (6): Chi-square test for functional analysis \& criteria of selection of materials

\begin{tabular}{|c|c|c|c|}
\hline & Value & df & $\begin{array}{c}\text { Asymp. Sig. } \\
(2 \text {-sided })\end{array}$ \\
\hline Pearson chi-square & $6.25^{\text {a }}$ & 2 & .732 \\
\hline
\end{tabular}

a. Result: There was a significant association at 0.05 level of significance

4. Hypothesis four: There is no relation between the methods of evaluation of alternatives and the criteria used in selection of materials and components to be incorporated in project. 
Table (7): Association between "methods of evaluation of alternatives" \& "criteria of selection of materials"

\begin{tabular}{|c|c|c|c|c|c|c|}
\hline \multicolumn{6}{|c|}{ Ranking the criteria used to choose materials to be incorporated in the project } & Total \\
\hline & & & Very important & Important & $\begin{array}{c}\text { Not } \\
\text { import } \\
\text { ant at } \\
\text { all }\end{array}$ & \\
\hline \multirow{6}{*}{$\begin{array}{l}\text { Methods used by } \\
\text { the design team to } \\
\text { evaluate the } \\
\text { alternatives of } \\
\text { materials and } \\
\text { elements to be } \\
\text { incorporated in } \\
\text { design }\end{array}$} & \multirow[t]{2}{*}{ Voting } & count & 1 & 1 & 0 & 2 \\
\hline & & $\begin{array}{l}\text { \%of } \\
\text { total }\end{array}$ & $6.7 \%$ & $6.7 \%$ & 0 & $13.3 \%$ \\
\hline & \multirow[t]{2}{*}{$\begin{array}{l}\text { Subjective } \\
\text { evaluation }\end{array}$} & count & 4 & 3 & 6 & 13 \\
\hline & & $\begin{array}{l}\text { \%of } \\
\text { total }\end{array}$ & $26.7 \%$ & $\% 20$ & $40 \%$ & $86.7 \%$ \\
\hline & \multirow[t]{2}{*}{ Total } & count & 5 & 4 & 6 & 15 \\
\hline & & $\begin{array}{l}\text { \%of } \\
\text { total }\end{array}$ & $33.3 \%$ & $26.7 \%$ & $40 \%$ & $100 \%$ \\
\hline
\end{tabular}

Table (8):Chi-square Test for Methods of Evaluation of Alternatives \& Criteria of Selection of Materials (cost)

\begin{tabular}{|c|c|c|c|}
\hline & Value & df & $\begin{array}{c}\text { Asymp. Sig. } \\
\text { (2-sided) }\end{array}$ \\
\hline $\begin{array}{c}\text { Pearson chi- } \\
\text { square }\end{array}$ & $2.587^{\mathrm{a}}$ & 2 & .452 \\
\hline
\end{tabular}

a. Result: There was a significant association at 0.05 level of significance

Testing of the research hypotheses revealed that there was no relation between the client's requirements and the client's brief conducted by the designer. The result means that the client was not satisfied with the design since his requirements and needs were not fulfilled.

Testing of the research hypothesis also revealed that there was no relation between the client's requirements and the criteria used in selection of materials and components to be incorporated in the project. No relation was observed between functional analysis and the criteria used in selection of materials and components to be incorporated in project. The results of the hypotheses test registered no relation between the methods of evaluation of alternatives and the criteria used in selection of materials and components to be incorporated in project. Within recent years, it has been considered 
that briefing is ongoing throughout the early stages of a project rather than a checklist or a document produced at a single point in time. The multidimensions of a client, commissioning and user should be represented in the briefing process. User participation in the design processes is considered a good mechanism for increasing the levels of satisfaction with the completed building. Inclusion of the human dimension, dialogue to provoke ideas and resolve conflicting needs, is considered a key feature of successful briefing (Luck etal 2001). Traditionally, a project is considered successful if the building is delivered at the right time, price, and quality. It should also provide the client with a high level of satisfaction. Still, a comprehensive list of criteria contributing to project success is lacking. (Chan et al. 2002).

Value engineering as a technique is not well known in Sudan even among professionals although it is applied successfully in many countries all over the world. The design firms in Sudan are really practicing VE principles partially in a limited scale without being aware of it; but VE is an integrated system having an organized job plan for its application. Hence, the results seem to be reliable and reflect the poor performance due to the unsystematic procedure practiced on the design process. Hogg (1999) stated that there are many possible factors created during the design process that cause poor value in construction. Those factors that may have a negative impact during design could include limitations on design time making error or incompleteness; outdated specifications; poor communications between client and designer; poor coordination of design consultants. In addition, the nature of the design process could be one of the causes of poor value. Bramble and Cipollini (1995) reported that many construction problems are due to design defects and can be traced back to the design process. The optimum balance between cost, quality, time and environmental issues is the challenge that it faces to achieve the functional value of facilities that are the main concern of the industry. VE becomes a useful tool to attain a balance among all these factors. Hence, the construction industry has the highest rate of applying VE (Fong, Yim 1999). The effectiveness of VE comes when it is integrated into the whole design process and becomes an integral element of it (Omigbodun 2001). Hence, the results of the hypotheses are consistent with the findings of the literature review. Poor performance in the design process could be improved if VE techniques and methods of analysis are used. 


\section{CONCLUSIONS}

1. Increase in cost and time and poor quality, which are the symptoms of the construction projects in Sudan, are due to many factors, which can be summarized as follows:

a. The process followed at the design firms is not efficient to obtain the true requirements and needs of the client at the brief stage. Hence, clients are not entirely satisfied with the produced designs and ask for changes and alterations to fulfill their needs.

b. Most of the designers are interested in showing their capabilities and therefore they produce very sophisticated and expensive designs.

After studying the results obtained from the questionnaire analysis, conclusions from hypotheses testing are:

i. The survey provided a very strong evidence to support the hypothesis that there is no relationship between the client's requirements and the client's brief conducted by the designer.

ii. The survey provided a very strong evidence to support the hypothesis that there is no relationship between the client's requirements and the criteria used for the selection of materials and components to be incorporated in projects.

iii. The survey provided a very strong evidence to support the hypothesis that there is no relationship between functional analysis and the criteria used for the selection of materials and components to be incorporated in projects.

\section{Recommendations}

1. The government should take the first step to adopt VE in the construction industry due to its various benefits in optimizing costs and improving the quality of the construction projects.

2. To carry out the recommendation mentioned above, the government should establish a department to take care of VE through setting laws and regulations to organize this methodology. The department is preferable to be attached to the Ministry of Finance or to the 
Ministry of the Council of Ministers to have power among other departments.

3. The government should issue a circular to all the engineering departments to organize the application of Value engineering studies on the engineering projects. VE studies should be attached as one of the contract documents in case of design, construction, operation and maintenance, if the cost of the project is greater than fifty million SD.

4. The private sector should also adopt VE as an efficient tool to increase the profit of their projects without sacrificing other properties.

The Faculties of Engineering and Architecture are supposed to teach $\mathrm{VE}$ as part of the construction management syllabus to spread the knowledge on this subject.

5. Managers of the design firms should get use of the techniques of VE in evaluation and selection of alternatives to promote the design process.

6. Architects should use models, computers, and other means that make the ordinary client to visualize and understand the required design easily.

7. The Engineering Society should play part in spread of this new methodology through workshops and seminars. Engineers who are aware of VE should be encouraged to write papers on this subject and to be published in the appropriate magazines.

\section{References}

1. Al-Yousifi, A. (2000). Value Management Concept and Techniques, K.S.A.

2. Al-Yousifi, A. (2005). "Journal interview about VE." J. of Amar, 90, 2630.

3. Al-Khoitter, A. M. (2000). VE Applications, Riyad, K.S.A.

4. Bramble, B.B. and Cipollini, M.D. (1995). National cooperative highway research program synthesis of highway practice 214 : 
Resolution of disputes to avoid construction claims, Tranportation Research Board, National Research Council, Washington D.C.

5. Chan, A.P.C; Scott, D.and Lam, E.W.M. (2002). "Framework of Success Criteria for Design/ Build Projects.” J. of Management in Engineering, 18(3), 120-128.

6. Fong, P.S. and Yim, E.K. (1999). "Charting the future directions of value engineering." SAVE International Proceedings.

7. Foster, G. (1986). Building Organization and Procedures, U.K.

8. George, D. and Palmer, A. (1995). Construction Management New Direction, Blackwell Sciences.

9. Gernerd, K.A. (1993). Successful application of value engineering at conceptual stage of design, SAVE Proceedings, Fort Lauderdale, Florida.

10. Grosvenor, R. (1997). "Introduction to value management." J. of Value Manager (Hong Kong), 3(4), 11-20.

11. Hogg, K. (1999). "The impact of sequential thinking in the construction design process." SAVE International Proceedings.

12. Luck, R., Haenlein, H. and Bright, K. (2001). "Project briefing for accessible design." J. of Design Studies, 22(3), 297-315.

13. O'Brien, J.J. (1976). Value analysis in design and construction. McGraw-Hill, New York.

14. Omigbodun, A. (2001). "Value Engineering and optimal building projects." J. of Architectural Engineering, 7(2), 40-43.

15. SAVE International (2000). Web site: www.value-eng.org.

16. Wuebbenhorst, K L. (1984). "Life cycle costs in the West Germany construction industry." Transaction of the American Association of Cost Engineers, (6), 24-27. 